\title{
The differences of the competencies of international logistics talents in Greater China: a comparison between Taiwan, Hong Kong and Mainland China
}

\author{
Chen Tao ${ }^{*}$
}

\begin{abstract}
As logistics talents in both Taiwan and Hong Kong are expanding their work area to Greater China, it is best to understand the competencies that logistics talents should possess. With this in mind, this study takes Mainland China, Hong Kong and Taiwan as the study scope, as well as logistics teaching and research experts and scholars as the study objects. The research findings can not only serve as informative references for universities intent on cultivating logistics talents, but as well as enhance the scope of both Taiwan and Hong Kong talents' competence that can pave the way to the development of the logistics business in Greater China.
\end{abstract}

Keywords: International logistics, Greater China, Analytic Hierarchy Process, Mainland China, Logistics talents

\section{Introduction}

'International logistics' has played a key role for international enterprises in welcoming the global challenge to integrate production and distribution. It is also one of the core competencies needed of $21^{\text {st }}$ century enterprises in order to enable them to compete among supply chains, and rapid response to market changes and customer requirements.

It is indubitable that human resources are a most important asset, and so efficient promotion of international logistics could only be done with the availability of suitable international logistics talents. The cultivation of such remarkable talents and development of professional skills in turn

Submission Date: 09/10/2008＿ Revision Date: 22/05/2009_ Acceptance Date: 22/05/2009

*Corresponding author, Assistant Professor, Department of Logistics and Shipping Management, Kainan University, Taiwan. E-mail: chentao@mail.knu.edu.tw, Fax:886-3-3412361 
depend on university education. As international logistics talents in both Taiwan and Hong Kong are expanding their work area to Greater China, it is best to understand the competencies that international logistics talents should possess. Likewise, it is crucial to understand the situation of regional logistics, and its actual demand. With this in mind, this study takes Mainland China, Hong Kong and Taiwan as the study scope, as well as international logistics teaching and research experts and scholars as the study objects.

Analyses of the expert advice of relevant scholars based on literature review of international logistics activities are also undertaken. Moreover, building of suitable competence planning indexes, utilization of the Analytic Hierarchy Process (AHP) method to determine weights are done to enable comparison of differences in Taiwan, Hong Kong and Mainland China. The data gathered can serve as informative references for universities intent on cultivating international logistics talents, as well as enhance the scope of both Hong Kong and Taiwanese talents' competence that can meet future demand during continued development of international logistics in Mainland China.

\section{Review of literature and logistics development in Greater China}

\subsection{Definition of international logistics}

In 1998, Council of Logistics Management has defined 'logistics' as the process of planning, implementing, and controlling the efficient, effective flow and storage of goods, services, and related information from point of origin to point of consumption for the purpose of conforming to customer requirements. And this definition includes inbound, outbound, internal, and external movements, and return of materials for environmental purposes ${ }^{1}$. Furthermore, in response to global competition and as an improvement to enterprises' overall competitiveness, a remarkable change of logistics operation has taken place in recent years, and international logistics strategy has played a vital role in the global strategy of enterprise. As logistics may differ between countries, international logistics is an indispensable part of international trading, particularly since this facilitates trading between countries. Lambert and Stock (1999) pointed out that: "When entering into the international market by export, license, partnership and independent operation, international companies need to develop an operation mode different from integration of local logistics to build the transnational logistics operation network. Implementing this international logistics operation encompasses logistics competence, international accounting management, document management, transnational corporate culture, increasingly complicated and integrated logistics management, and analysis of total cost and benefits. By means of an integrated operation of transnational logistics, enterprises could reduce the operating cost, increasing the profit, meeting customer demand, enhancing the enterprises' overall competitive advantage and maximizing

\footnotetext{
${ }^{1}$ Council of Logistics Management, which has been renamed Council of Supply Chain Management Professional. http://www.clml.org/mission.html, 12 Feb 98
} 
performance of overall operation.

\subsection{Definition of professional skills of international logistics}

As previously stated in this paper, enterprises must obtain, integrate and use resources globally to be able to respond rapidly to the demand of different regions. Consequently, enterprises need a global logistics system. The development of international logistics and the training of its skills have been thoroughly studied by experts and scholars and the study results could be summarized into two categories: First, the study of skills training and the connotation of logistics courses as referenced in education and training organizations, and second, the analysis and comparison of professional skills that logistics professionals should possess, including knowledge, skill and attitude. For example, Murphy and Poist (1991, 1994 and 1998) have analyzed the demand of logistics skills for high-ranking and senior managers and have likewise put forward concepts of business knowledge and competence, logistics knowledge and competence, and management knowledge and competence through a BLM (Business Logistics Management) model. On the other hand, Gammelgaard and Larson (2001) categorized the skills of managers in the supply chain into three categories. The first is interpersonal or basic management skill, the second is quantitative or information skill, and the third is supply chain management skill. In view of vast volume of literature and the sophisticated training program, the major differences in the literature surveyed are listed in Tables 1 and 2 based on Interpersonal Management Knowledge/Skills and Logistics Knowledge/Skills.

Table 1

Interpersonal management knowledge and skills analysis

\begin{tabular}{|c|c|c|c|c|c|c|}
\hline Skills & $\mid \begin{array}{c}\text { William \& } \\
\text { Curry (1990) }\end{array}$ & $\begin{array}{c}\text { Murphy et al } \\
(1991,1994, \\
1998) \\
\end{array}$ & $\begin{array}{c}\text { Grammelgaard et al } \\
\text { (2001) }\end{array}$ & $\begin{array}{c}\text { Stock \& } \\
\text { Lambert } \\
(2001) \\
\end{array}$ & $\begin{array}{c}\text { Mohammed \& } \\
\text { Mas (2001) }\end{array}$ & Total \\
\hline $\begin{array}{c}\text { Management } \\
\text { Ability }\end{array}$ & 0 & 0 & 0 & 0 & 0 & 5 \\
\hline Strategic Ability & & ○ & & ○ & o & 3 \\
\hline $\begin{array}{l}\text { Personal } \\
\text { Qualities }\end{array}$ & 0 & 0 & & & 0 & 3 \\
\hline Negotiation Skills & & ० & ० & o & 0 & 4 \\
\hline $\begin{array}{c}\text { Communication } \\
\text { Ability }\end{array}$ & 0 & 0 & 0 & 0 & 0 & 5 \\
\hline Analytical Ability & & o & o & & o & 3 \\
\hline
\end{tabular}

Source: sorted by author 
Table 2

Business and logistics knowledge/skills analysis

\begin{tabular}{|c|c|c|c|c|c|c|c|c|c|c|}
\hline $\begin{array}{c}\text { Knowledge } \\
\& \text { Skills }\end{array}$ & $\begin{array}{c}\text { Ballou \& } \\
\text { Piercy } \\
(1974) \\
\end{array}$ & $\begin{array}{c}\text { William } \\
\text { et al } \\
(1990) \\
\end{array}$ & $\begin{array}{c}\text { Murphy } \\
\text { et al }(1991 \text {, } \\
1994,1998) \\
\end{array}$ & $\begin{array}{l}\text { Dadzie } \\
(1998)\end{array}$ & $\begin{array}{c}\text { Grammelgaard } \\
\text { et al (2001) }\end{array}$ & \begin{tabular}{|c|} 
Stock \\
et al \\
$(2001)$ \\
\end{tabular} & $\begin{array}{l}\text { Mohammed } \\
\text { et al (2001) }\end{array}$ & $\begin{array}{c}\text { Max } \\
(2002)\end{array}$ & $\begin{array}{l}\text { Leslie } \\
(2005)\end{array}$ & Total \\
\hline $\begin{array}{c}\text { Language } \\
\text { Skills \& } \\
\text { Ability }\end{array}$ & & & 0 & & 0 & & & & & 2 \\
\hline $\begin{array}{c}\text { Logic \& } \\
\text { Mathematic } \\
\text { al Ability }\end{array}$ & & & 0 & 0 & ○ & & o & 0 & & 5 \\
\hline $\begin{array}{c}\text { Modern } \\
\text { Knowledge }\end{array}$ & & 0 & 0 & & 0 & & o & o & & 5 \\
\hline Management & & o & o & o & o & ○ & o & ० & o & 8 \\
\hline $\begin{array}{c}\text { Electronic } \\
\text { Business }\end{array}$ & & 0 & 0 & 0 & o & O & 0 & & o & 7 \\
\hline Law & & & 0 & 0 & & & o & 0 & o & 5 \\
\hline $\begin{array}{c}\text { Supply } \\
\text { Chain \& } \\
\text { Logistics } \\
\text { Management }\end{array}$ & 0 & 0 & 0 & o & o & 0 & O & O & o & 9 \\
\hline $\begin{array}{c}\text { International } \\
\text { Transport } \\
\text { Management }\end{array}$ & o & & 0 & 0 & & & O & o & o & 6 \\
\hline
\end{tabular}

Source: Sorted by author

As a conclusion to the above literature review, it can be stated that international logistics is multinational due to the evolution of economic forms, and has, from a single logistics function (freight, warehousing, packaging and handling), been transformed to a knowledge based operation that along with a demand integrated ability, covers logistics, capital flow, business and information technology. For this reason, it involves language courses, metering analysis (logic and math) skills, business management, $e$-business, international transportation, supply chain and logistics, and other knowledge related with the business environment. These then serve as competencies that an international logistics talent must possess and which provide an important implication in course planning. 


\subsection{Trade flow and logistics development in Greater China}

Greater China includes three major regions: Mainland China, Hong Kong, and Taiwan. As shown in Table 3, there are strong economic links among them. Take Mainland China for example, in 2007, the value of cargo it imported from Taiwan was around US\$101 billion, or $10.5 \%$ of its total import value, while the value of cargo it exported to Hong Kong was around US\$184 billion, or $15.1 \%$ of its total export value.

In Taiwan, around $25.3 \%$ of the total export value goes to China; around $15.4 \%$ of export value goes to Hong Kong; and around $12.8 \%$ of its total import value comes from China. Moreover, the economic links between Hong Kong and Mainland China is even closer; for example, around $46.4 \%$ of the import value of Hong Kong comes from Mainland China and around $48.7 \%$ of export/transship value goes to Mainland China.

Table 3

Trade flow within Greater China

\begin{tabular}{|c|c|c|c|}
\hline & & Taiwan & Hong Kong \\
\hline \multirow{2}{*}{$\begin{array}{c}\text { China } \\
\text { (US \$billion) }\end{array}$} & Import from & $101.0(10.5 \%)$ & n.a. \\
\hline & Export to & n.a. & $184.4(15.1 \%)$ \\
\hline & & China & Hong Kong \\
\hline \multirow{2}{*}{$\begin{array}{c}\text { Taiwan } \\
\text { (NT \$billion) }\end{array}$} & Import from & $921(12.8 \%)$ & n.a. \\
\hline & Export to & $2,045(25.3 \%)$ & $1,245(15.4 \%)$ \\
\hline & & China & Taiwan \\
\hline \multirow{2}{*}{$\begin{array}{l}\text { Hong Kong } \\
\text { (HK \$billion) }\end{array}$} & Import from & $1,329(46.4 \%)$ & $205.0(7.2 \%)$ \\
\hline & Export/Transship to & $1,307(48.7 \%)$ & $52.9(1.9 \%)$ \\
\hline
\end{tabular}

Source: China Customs Statistics 2008, Ministry of Finance, Taiwan, Census and Statistics Department, Hong Kong.

According to the survey made by World Bank in 2007, there are huge differences in the logistics development among Greater China regions (as shown in Table 4). For example, in the indicator of 'Logistics Performance Rank', Hong Kong ranked $8^{\text {th }}$ in the world, Taiwan ranked $21^{\text {st }}$, and China $30^{\text {th }}$. As for other indicators, Hong Kong was always the best among the three regions, Taiwan second, and China third. The only indicator that ranked Hong Kong third was 'Domestic Logistics Costs'.

Thus, in respect to the level of logistics development, Hong Kong is the most advanced one, Taiwan is in a moderate position, and Mainland China is in the developing stage. The great differences among regions in Greater China in the international logistics development put Mainland China in a perfect position to recruit logistics expertise from the other two regions during different stages of logistics development. 
Table 4

Comparison of logistics performance in Greater China regions

\begin{tabular}{c|c|c|c}
\hline & Taiwan & Hong Kong & China \\
\hline \hline Logistics Performance Rank & 21 & 8 & 30 \\
International Shipments Rank & 17 & 7 & 28 \\
Logistics Competence Ranking & 23 & 9 & 27 \\
Domestic Logistics Costs Rank & 42 & 119 & 72 \\
\hline
\end{tabular}

Source: World Bank (2007), Trade Logistics in the Global Economy.

The rapid growth of logistics businesses in Mainland China requires high quality and large number of logistics talents. According to the report made by the Ministry of Education, China in 2007, the demand for high-quality logistics talents will increase by $15 \%$ annually, but the education institutes could only provide around 14\% of that demand. More specifically, in 2010, the demand for university-graduated logistics talents will be around 300,000 to 400,000, and the demand for logistics staff for on-the-job training will be around one million.

Clearly, there are strong economic links among Mainland China, Hong Kong, and Taiwan. In the meantime, because of the huge demand for logistics professionals in China, Taiwan and Hong Kong have a great opportunity to export professionals to Mainland China. Therefore, it is essential for logistics talents in both Hong Kong and Taiwan to realize the demand in Mainland China and even bigger business opportunities in Greater China.

\section{Research design}

\subsection{Research background}

The study of the competencies of international logistics talents started in 2005. The first study interviewed senior managers in the international logistics industry in Taiwan to find out what are the most important competencies needed (Chen \& Chiang, 2006). The second study examined the differences between senior managers and the academics in the competencies of international logistics, and summarized the major gaps between them; the findings have been used to restructure the teaching courses in international logistics departments in Taiwan (Chen \& Chiang, 2007). Based on the findings of previous researches, this study would like to expand its scope to Greater China regions. The first stage is to find out the differences among the academics in the three regions and the second step is to collect the responses from senior managers in the international logistics industry in Greater China. This research hopes to help international logistics talents and academic institutes in both Hong Kong and Taiwan to realize the demand for competences and skills in Mainland China and help talents expand their business opportunities. 


\subsection{Analytic hierarchy process and appraisal structure}

In 1971, Saaty proposed the Analytic Hierarchy Process, hereinafter referred to as AHP (Saaty, 1980). The AHP could systemize complicated problems by hierarchical breakdown, demonstrate the importance of each criteria by calculating their weight, and quantify the comprehensive appraisal to provide suitable information to decision makers. In this regard, this study aims to conduct a quantitative analysis on the demand for basic competence in international logistics from the academic angle of Taiwan, Hong Kong and Mainland China, build competence indexes, and calculate their weights in the hope of providing a reference to relevant educating organizations to revise their talent training course. This study is carried out through the AHP method because it conforms to its application scope.

To understand how university graduates are trained to possess an integrated ability based on international logistics, this study initially sorts out various literature related with logistics professional skills. Designs for the questionnaire's draft of the international logistics talent's competence, is then done by examining and filtering the logistics courses. Subsequently, a pretest answered by both industry experts and scholars is carried out, and finally, building of the Analytic Hierarchy Structure (Chen \& Chiang, 2006, 2007) (as shown in Table 5).

The study questionnaire is based on the above design structure and its indexes cover integrated courses such as logistics, business administration, information management, and laws and regulations. It has a total of three major indexes, nine secondary assessment criteria, and 29 assessment items. Notably, it evaluates the relevant significance of pairs of indexes, compares the three major indexes, and then compares other assessment criteria with the assessment plan.

\subsection{Sample selection and questionnaire distribution}

To find out the right people and the academic institutes to answer the questionnaire, two criteria were used to select the respondents. The first is that the academic institutes must offer the above-mentioned undergraduate courses (as shown in Table 5). Furthermore, to ensure that the professors in the institute have close links and frequent interactions with the international logistics industry, the institute must offer Executive MBA courses for senior managers ${ }^{2}$. That way, the questionnaires collected from the professors of these institutes were expected to meet the demand of this research.

After a comprehensive survey of the academic institutes in Greater China, the institutes that meet the above-mentioned conditions were identified (as shown in Table 6). The senior professors of these institutes were interviewed during the 2005 and 2006 Greater China Logistics Conferences held in Nanjin and Hong Kong.

\footnotetext{
${ }^{2}$ In Taiwan and Mainland China, this type of postgraduate program is called 'Executive MBA', but in Hong Kong, the same program is called 'part-time' MSC, which is offered in Hong Kong Polytechnic University.
} 
Table 5

AHP structure of international logistics talents skill course planning

\begin{tabular}{|c|c|c|}
\hline First Layer & Second Layer & Third Layer \\
\hline \multirow{3}{*}{$\begin{array}{l}\text { A. General } \\
\text { education and basic } \\
\text { skills }\end{array}$} & A1. Language skills & $\begin{array}{l}\text { A11. Chinese } \\
\text { A12. English } \\
\text { A13. Second foreign language }\end{array}$ \\
\hline & A2. Logic and math & $\begin{array}{l}\text { A21. Basic Mathematics } \\
\text { A22. Business management basic courses } \\
\text { A23. Intermediate mathematics }\end{array}$ \\
\hline & A3. Modern knowledge & $\begin{array}{l}\text { A31. Word, Excel } \\
\text { A32. Internet application } \\
\text { A33. International and domestic current situation }\end{array}$ \\
\hline \multirow{3}{*}{$\begin{array}{l}\text { B. Business } \\
\text { management and } \\
\text { IT professional } \\
\text { skills }\end{array}$} & B1. Business management & $\begin{array}{l}\text { B11. International business and trade management } \\
\text { B12 Business management professional knowledge } \\
\text { B13. Strategic planning }\end{array}$ \\
\hline & B2 Corporate e-process & $\begin{array}{l}\text { B21. E-business } \\
\text { B22. Information management } \\
\text { B23. Information Technology }\end{array}$ \\
\hline & B3. Law and administration & $\begin{array}{l}\text { B31. Administrative rules } \\
\text { B32. Basic legal knowledge } \\
\text { B33 Industrial policy }\end{array}$ \\
\hline \multirow{3}{*}{$\begin{array}{l}\text { C. International } \\
\text { logistics } \\
\text { professional skills }\end{array}$} & $\begin{array}{l}\text { C1. Supply chain and logistics } \\
\text { management }\end{array}$ & $\begin{array}{l}\text { C11. Logistics management } \\
\text { C12. Supply chain management } \\
\text { C13. Warehousing and logistic center management } \\
\text { C14. International logistics management }\end{array}$ \\
\hline & $\begin{array}{l}\mathrm{C} 2 \text {. Intemational transportation } \\
\text { management }\end{array}$ & $\begin{array}{l}\text { C21. Transportation management } \\
\text { C22 Ocean and air transportation management } \\
\text { C23. International transportation regulations and insurance } \\
\text { C24 Transportation planning }\end{array}$ \\
\hline & C3. Topic study and practice & $\begin{array}{l}\text { C31. Topic study } \\
\text { C32 Site visit } \\
\text { C33 Practice }\end{array}$ \\
\hline
\end{tabular}


Taiwan, Hong Kong and Mainland China

Table 6

The academic institutes selected in Greater China

\begin{tabular}{c|c|l}
\hline Region & University & \multicolumn{1}{c}{ Department / Research Center } \\
\hline \hline $\begin{array}{c}\text { Mainland } \\
\text { China }\end{array}$ & $\begin{array}{c}\text { Nankai University } \\
\text { SouthEast University }\end{array}$ & $\begin{array}{l}\text { Research Center of Logistics } \\
\text { College of Transport } \\
\text { College of Transport and Communication / Logistics } \\
\text { Research Center } \\
\text { Shanghai Maritime University }\end{array}$ \\
& Dalian Maritime University & College of Transport and Communication \\
\hline \multirow{2}{*}{ Hong Kong } & Hong Kong Polytechnic University & Department of Logistics and Maritime Studies \\
& National Taiwan Ocean University & Department of Shipping Transport Management \\
& Chang Jung University & $\begin{array}{l}\text { Department of Aviation and Maritime Transport } \\
\text { Management }\end{array}$ \\
\hline
\end{tabular}

\section{Research result and discussion}

\subsection{Objects of the questionnaire}

The objects of this study were senior professors from international logistics faculties in Mainland China, Hong Kong and Taiwan. A total of 29 questionnaires were distributed and collected in 2006. After the consistency test, 29 valid questionnaires were collected; the validity rate was $100 \%$. Table 7 summarizes the distribution and collection of questionnaires.

Table 7

Questionnaire statistics

\begin{tabular}{c|c|c|c|c}
\hline Area & Mainland China & Hong Kong & Taiwan & Total \\
\hline \hline $\begin{array}{c}\text { Questionnaire } \\
\text { distributed (copies) }\end{array}$ & 9 & 6 & 14 & 29 \\
$\begin{array}{c}\text { Questionnaire } \\
\text { collected (copies) }\end{array}$ & 9 & 6 & 14 & 29 \\
Collection rate (\%) & 100 & 100 & 100 & 100 \\
Validity rate & 100 & 100 & 100 & 100 \\
\hline
\end{tabular}




\subsection{Analysis of weight in Taiwan, Hong Kong and Mainland China}

This study had Mainland China, Hong Kong and Taiwan as the study scope, and the senior professors of international logistics as the study objects. The AHP data analysis on the questionnaires was conducted through Microsoft Excel. The results are shown in the Tables below with each result discussed, as follows:

\section{First layer}

Study results (as shown in Table 8) indicate that, under the first layer categories, both Taiwan and Hong Kong professors consider the professional skills in international logistics as being the most important. This is followed by general education and basic skills, and finally by business management and IT professional skills.

The Mainland China professors however believe that business management and IT professional skills are the most important, followed by general education and basic skills, and finally by professional skills in international logistics.

These results may be attributed to the fact that Mainland China is an emerging market in the world, that its logistics industry falls behind Taiwan and Hong Kong, and that it is still a labor and capital-intensive market. Due to lack of business managers, Mainland China apparently needs to cultivate talents with professional skills in business management and information technology. The rather mature logistics industry in Hong Kong and Taiwan allows students the opportunity to improve their professional knowledge in international logistics in order to adapt to the rapidly changing environment. Therefore professional skills in international logistics are regarded as the teaching emphasis.

Table 8

Comparison of items under the target dimension

\begin{tabular}{c|c|c|c}
\hline Layer 1 Index & $\begin{array}{c}\text { A. General } \\
\text { education and basic } \\
\text { skills }\end{array}$ & $\begin{array}{c}\text { B. Business management and } \\
\text { IT professional skills }\end{array}$ & $\begin{array}{c}\text { C. International logistics } \\
\text { professional skills }\end{array}$ \\
\hline \hline \multirow{2}{*}{ Taiwan } & 0.215 & 0.200 & 0.585 \\
\cline { 2 - 4 } & $\lambda_{\max }=3.04955$, C.I.H. $=0.02477$, C.R.H. $=0.04271$ & 0.416 \\
\hline \multirow{2}{*}{ Hong Kong } & 0.368 & 0.216 & 0.236 \\
\cline { 2 - 4 } & $\lambda_{\max }=3.05026$, C.I.H. $=0.02513$, C.R.H. $=0.04332$ \\
\hline \multirow{2}{*}{$\begin{array}{c}\text { Mainland } \\
\text { China }\end{array}$} & \multicolumn{2}{|c|}{0.326} & 0.438 \\
\cline { 2 - 4 } & $\lambda_{\max }=3.03881$, C.I.H. $=0.01940$, C.R.H. $=0.03346$ \\
\hline
\end{tabular}

\section{Second layer}

Regarding the dimension of the nine criteria in subject, supply chain and logistics 
management is the essential and important basic skill in international logistics. Professors in Taiwan and Hong Kong, in particular, attach great importance to it (as shown in Table 9). Nevertheless, Hong Kong has a wider internationalization extent besides better software and hardware logistics infrastructures than Taiwan. Cooperation between the industry and academic circle has, in fact, developed to a certain scale.

Of note, Hong Kong professors pay more attention to the Language skills, while Taiwan renders greater value to topic study and practice with the hope of increasing the practical experience of students.

Table 9

Comparison of criteria in layer two

\begin{tabular}{|c|c|c|c|}
\hline Layer 2 Index & A1. Language skills & A2. Logic and math & A3. Modern knowledge \\
\hline \multirow{2}{*}{ Taiwan } & 0.080 & 0.083 & 0.051 \\
\hline & \multicolumn{3}{|c|}{$\lambda_{\max }=3.02506$, C.I.H. $=0.01253$, C.R.H. $=0.02160$} \\
\hline \multirow{2}{*}{ Hong Kong } & 0.277 & 0.052 & 0.039 \\
\hline & \multicolumn{3}{|c|}{$\lambda_{\max }=3.50154$, C.I.H. $=0.03649$, C.R.H. $=0.06291$} \\
\hline \multirow{3}{*}{$\begin{array}{c}\text { Mainland } \\
\text { China }\end{array}$} & 0.098 & 0.134 & 0.094 \\
\hline & \multicolumn{3}{|c|}{$\lambda_{\max }=3.05704$, C.I.H. $=0.02852$, C.R.H. $=0.04917$} \\
\hline & B1. Business management & B2 Corporate e-process & $\begin{array}{l}\text { B3. Law and } \\
\text { administration }\end{array}$ \\
\hline \multirow{2}{*}{ Taiwan } & 0.065 & 0.081 & 0.054 \\
\hline & \multicolumn{3}{|c|}{$\lambda_{\max }=3.03655$, C.I.H. $=0.01827$, C.R.H. $=0.03151$} \\
\hline \multirow{2}{*}{ Hong Kong } & 0.094 & 0.047 & 0.075 \\
\hline & \multicolumn{3}{|c|}{$\lambda_{\max }=3.02782$, C.I.H. $=0.01391$, C.R.H. $=0.02399$} \\
\hline \multirow{3}{*}{$\begin{array}{l}\text { Mainland } \\
\text { China }\end{array}$} & 0.179 & 0.105 & 0.154 \\
\hline & \multicolumn{3}{|c|}{$\lambda_{\max }=3.05194$, C.I.H. $=0.02597$, C.R.H. $=0.04477$} \\
\hline & $\begin{array}{l}\text { C1. Supply chain and logistics } \\
\text { management }\end{array}$ & $\begin{array}{l}\text { C2. International } \\
\text { transportation } \\
\text { management }\end{array}$ & $\begin{array}{l}\text { C3. Topic study and } \\
\text { practice }\end{array}$ \\
\hline \multirow{2}{*}{ Taiwan } & 0.231 & 0.152 & 0.202 \\
\hline & \multicolumn{3}{|c|}{$\lambda_{\max }=3.03488$, C.I.H. $=0.01744$, C.R.H. $=0.03007$} \\
\hline \multirow{2}{*}{ Hong Kong } & 0.177 & 0.164 & 0.075 \\
\hline & \multicolumn{3}{|c|}{$\lambda_{\max }=2.59410$, C.I.H. $=0.01133$, C.R.H. $=0.01954$} \\
\hline \multirow{2}{*}{$\begin{array}{c}\text { Mainland } \\
\text { China }\end{array}$} & 0.087 & 0.043 & 0.106 \\
\hline & \multicolumn{3}{|c|}{$\lambda_{\max }=3.07514$, C.I.H. $=0.03757$, C.R.H. $=0.06478$} \\
\hline
\end{tabular}


In contrast, among mainland universities, business management is considered the most important in the top three courses, followed by law and administration, and finally by the logic and math ability. This may be due to Mainland China's as of yet budding logistics development. It is worth mentioning that universities in Mainland China have different preferences in cultivating student skills.

\section{Third layer}

\section{Based on general education and basic skills}

In terms of the dimension of the 29 courses, primarily the aspect of general education and basic skills, excellent English skills in the international logistics industry can assist enterprises in globalization, expansion of the operation and augmentation of profit. Consequently, improvement of the students' language abilities is the apt response to the urgent demand (as shown in Table 10).

Table 10

Comparison based on general education and basic skills

\begin{tabular}{c|c|c|c}
\hline Layer 3 Index & Taiwan & Hong Kong & Mainland China \\
\hline \hline A11. Chinese & 0.076 & 0.204 & 0.121 \\
A12.English & 0.243 & 0.382 & 0.114 \\
A13. Second foreign language & 0.056 & 0.166 & 0.065 \\
\hline
\end{tabular}

Taiwan: $\lambda_{\max }=3.06658$, C.I.H. $=0.03329$, C.R.H. $=0.05740$

Hong Kong: $\lambda_{\max }=3.04196$, C.I.H. $=0.02098$, C.R.H. $=0.03617$

Mainland China: $\lambda_{\max }=3.04227$, C.I.H. $=0.02113$, C.R.H. $=0.03644$

\begin{tabular}{c|c|c|c}
\hline Layer 3 Index & Taiwan & Hong Kong & Mainland China \\
\hline \hline A21. Basic Mathematics & 0.116 & 0.063 & 0.143 \\
A22. Business management basic courses & 0.057 & 0.051 & 0.097 \\
A23. Intermediate mathematics & 0.214 & 0.049 & 0.171 \\
\hline
\end{tabular}

Taiwan: $\lambda_{\max }=3.02072$, C.I.H. $=0.01036$, C.R.H. $=0.01787$

Hong Kong: $\lambda_{\max }=3.02964$, C.I.H. $=0.01482$, C.R.H. $=0.02556$

Mainland China: $\lambda_{\max }=3.05428$, C.I.H. $=0.02714$, C.R.H. $=0.04680$

\begin{tabular}{c|c|c|c}
\hline Layer 3 Index & Taiwan & Hong Kong & Mainland China \\
\hline \hline A31. Word, Excel & 0.103 & 0.021 & 0.127 \\
A32. Internet application & 0.074 & 0.016 & 0.088 \\
A33. International and domestic current \\
situation & 0.061 & 0.047 & 0.074 \\
\hline
\end{tabular}

Taiwan: $\lambda_{\max }=3.04249$, C.I.H. $=0.02125$, C.R.H. $=0.03663$

Hong Kong: $\lambda_{\max }=3.03746$, C.I.H. $=0.01873$, C.R.H. $=0.03229$

Mainland China: $\lambda_{\max }=3.04869$, C.I.H. $=0.02435$, C.R.H. $=0.04198$ 
This is evident in the Taiwan and Hong Kong professors' value of English skills training. Having the most extensive internationalization degree, Hong Kong likewise pays attention to Chinese and another foreign language (of second and third priorities, respectively). Except for English skills, Taiwan also considers good mathematical reasoning ability as able to improve the students' logical reasoning and thought-organizing ability, which is the important foundation for various disciplines of science.

In view of the working needs in the future, Taiwan pays specific attention to basic mathematics, calculus, statistics, accounting, economy and so forth for business management. This view is similar to Mainland China's current stage of development

\section{Based on business management and IT professional skills}

Concerning the aspect of professional skills in business management and information technology, and based on the data analysis in this study, Taiwan is actively developing e-business and other fields, with special attention to e-business, information management and other skills since the recent development of the e-commerce and web based service to a certain scale (as shown in Table 11).

Moreover, due to the uncertain relationship between Mainland China and Taiwan, professors in both vicinities pay attention to the changing industrial policy. With less interference of political elements, Hong Kong, in contrast, gives emphasis on skills training of managing international enterprises as well as strategic planning. It is evident that professors from Taiwan, Hong Kong and Mainland China have varying opinions on this dimension.

\section{Based on professional skills in international logistics}

On the subject of professional skills in international logistics, there are some interesting findings among the university education of logistics between Hong Kong, Taiwan, and Mainland China (as shown in Table 12). For example, supply chain management is the only professional skill marked with high weight (higher than 0.1) by all of these. Regarding other skills, both Hong Kong and Taiwan professors are of the opinion that supply chain management and transportation management are important skills. Regarding the most important skill (which is marked with highest weight), Hong Kong professors think 'logistics management' should be the most important skill. However, since professors in China and Taiwan think 'practice' is the most important course, by way of practice in the industry, the students will be able to obtain the practical professional skills needed.

Generally speaking, only three skills have been weighted over 0.1 by professors in both Hong Kong and Taiwan. However, there are six items that have been weighted over 0.1 by professors in Mainland China, with the top three skills all located in C3, which refers to topic study and practice. One possible explanation for this is that the professional knowledge taught by teaching programs (which are mostly imported from foreign countries) may not be able to meet the demand of the fast growing logistics market in Mainland China. Therefore, topic study and practice has been considered as the most effective and efficient way for students to obtain the professional skills needed. 
Table 11

Comparison based on business management and IT professional skills

\begin{tabular}{c|c|c|c}
\hline Layer 3 Index & Taiwan & Hong Kong & Mainland China \\
\hline \hline $\begin{array}{c}\text { B11. International business and trade } \\
\text { management }\end{array}$ & 0.091 & 0.179 & 0.146 \\
\hline $\begin{array}{c}\text { B12 Business management professional } \\
\text { knowledge }\end{array}$ & 0.123 & 0.093 & 0.114 \\
\hline \begin{tabular}{c} 
B13. Strategic planning \\
\hline
\end{tabular}
\end{tabular}

\begin{tabular}{|c|c|c|c|}
\hline \multicolumn{4}{|c|}{$\begin{array}{l}\text { Taiwan: } \lambda_{\max }=3.02446 \text {, C.I.H. }=0.01223 \text {, C.R.H. }=0.02109 \\
\text { Hong Kong: } \lambda_{\max }=3.05418 \text {, C.I.H. }=0.02709 \text {, C.R.H. }=0.04671 \\
\text { Mainland China: } \lambda_{\max }=3.05963 \text {, C.I.H. }=0.02981 \text {, C.R.H. }=0.05140\end{array}$} \\
\hline Layer 3 Index & Taiwan & Hong Kong & Mainland China \\
\hline B21. E-business & 0.163 & 0.095 & 0.101 \\
\hline B22. Information management & 0.148 & 0.069 & 0.073 \\
\hline B23. Information Technology & 0.094 & 0.056 & 0.065 \\
\hline
\end{tabular}

Taiwan: $\lambda_{\max }=3.02941$, C.I.H. $=0.01471$, C.R.H. $=0.02536$

Hong Kong: $\lambda_{\max }=3.03496$, C.I.H. $=0.01748$, C.R.H. $=0.03014$

Mainland China: $\lambda_{\max }=3.05147$, C.I.H. $=0.02574$, C.R.H. $=0.04437$

\begin{tabular}{c|c|c|c}
\hline Layer 3 Index & Taiwan & Hong Kong & Mainland China \\
\hline \hline B31. Administrative rules & 0.065 & 0.128 & 0.082 \\
\hline B32. Basic legal knowledge & 0.074 & 0.120 & 0.120 \\
\hline B33 Industrial policy & 0.131 & 0.096 & 0.149 \\
\hline
\end{tabular}

Taiwan: $\lambda_{\max }=3.03048$, C.I.H. $=0.01524$, C.R.H. $=0.02628$

Hong Kong: $\lambda_{\max }=3.03217$, C.I.H. $=0.01609$, C.R.H. $=0.02774$

Mainland China: $\lambda_{\max }=3.04077$, C.I.H. $=0.02039$, C.R.H. $=0.03515$ 
Table 12

Comparison based on professional skills in international logistics

\begin{tabular}{c|c|c|c}
\hline Layer 3 Index & Taiwan & Hong Kong & Mainland China \\
\hline \hline C11. Logistics management & 0.076 & 0.143 & 0.102 \\
\hline C12. Supply chain management & 0.121 & 0.125 & 0.108 \\
\hline C13. Warehousing and logistic center management & 0.080 & 0.050 & 0.101 \\
\hline C14. International logistics management & 0.098 & 0.096 & 0.048 \\
\hline
\end{tabular}

Taiwan: $\lambda_{\max }=4.12753$, C.I.H. $=0.04251$, C.R.H. $=0.03428$

Hong Kong: $\lambda_{\max }=4.16825$, C.I.H. $=0.05608$, C.R.H. $=0.04523$

Mainland China: $\lambda_{\max }=4.19296$, C.I.H. $=0.06432$, C.R.H. $=0.05187$

\begin{tabular}{c|c|c|c}
\hline Layer 3 Index & Taiwan & Hong Kong & Mainland China \\
\hline \hline C21. Transportation management & 0.112 & 0.139 & 0.079 \\
\hline C22 Ocean and air transportation management & 0.050 & 0.097 & 0.023 \\
\hline $\begin{array}{c}\text { C23. International transportation regulations and } \\
\text { insurance }\end{array}$ & 0.075 & 0.098 & 0.052 \\
\hline C24 Transportation planning & 0.062 & 0.085 & 0.046 \\
\hline
\end{tabular}

$\mathrm{n}: \lambda_{\max }=4.18265$, C.I.H. $=0.06088$, C.R.H. $=0.04910$

Hong Kong: $\lambda_{\max }=4.29438$, C.I.H. $=0.09813$, C.R.H. $=0.07913$

Mainland China: $\lambda_{\max }=4.25151$, C.I.H. $=0.08384$, C.R.H. $=0.06761$

\begin{tabular}{c|c|c|c}
\hline Layer 3 Index & Taiwan & Hong Kong & Mainland China \\
\hline \hline C31. Topic study & 0.092 & 0.064 & 0.114 \\
\hline C32 Site visit & 0.077 & 0.036 & 0.142 \\
\hline C33 Practice & 0.157 & 0.067 & 0.185 \\
\hline
\end{tabular}

$\mathrm{n}: \lambda_{\max }=3.0258$, C.I.H. $=0.01290$, C.R.H. $=0.02225$

Hong Kong: $\lambda_{\max }=3.03212$, C.I.H. $=0.01606$, C.R.H. $=0.02769$

Mainland China: $\lambda_{\max }=3.04597$, C.I.H. $=0.02298$, C.R.H. $=0.03963$

\section{Conclusion}

This study aimed to discuss the competences of international logistics talents based on the viewpoints of professors in Mainland China, Hong Kong, and Taiwan, as well as understand the 
implication of the difference in education of international logistics in Taiwan, Hong Kong, and Mainland China. The results of the study would then serve as the educational organizations' future reference for teaching and curriculum planning.

In the meantime, this study collected materials from literature and advice from professionals to build the International Logistics Talents' Competence Curriculum Planning Index by AHP. It stipulated three categories, nine subjects, and twenty-nine courses, and carried out a questionnaire survey analyzing the current situation and comparing the differences among regions in Greater China. Overall, under the dimension of competence of international logistics talents, professors in Taiwan and Hong Kong believe that cultivation of professional skills in international logistics should be top priority. Mainland China professors, however, attach importance to competence in business management and information technology. As for appraisal courses, professors in these regions have quite differing views; roughly, the most important indexes are English ability, logic and Mathematics, logistics and supply chain management, international enterprise and trade management, and strategic planning study and corporate practice. These indicate that the abovementioned indexes are not only abilities that should be possessed by the international logistics talents, but are important references for teaching and curriculum improvement in educational organizations and universities.

The result of this research shows that there are huge differences between the concept of the competencies and curricula to be developed among professors in Hong Kong, Taiwan, and China. It is not a surprise to see this result, because the market size, characteristics of regional economy, and growth of the logistics market among Hong Kong, Taiwan, and China are all different. These factors have further forced professors in universities to design a curriculum to meet the regional demand. It is expected that the differences between regions in Greater China will not be changed. Furthermore, as discussed in 4.2, professors in China have placed more attention on topic study and practice. As a consequence, it could be expected that the comprehensive curriculum and teaching materials with Chinese characteristics would be developed soon. These will fully meet local demand and further strengthen the competitiveness of Chinese logistics talents.

With close economic links among regions of Greater China, and the increasing number of international logistics professionals in both Taiwan and Hong Kong being recruited by Mainland China enterprises, it is expected that there will be more professional moves within Greater China. As a consequence, academic institutes and talents should be prepared to expand their business scope beyond domestic demand to include Greater China.

This study limited its scope to 'international logistics' only, but for future research, both 'international' and 'domestic' logistics should be covered, because there are a number of differences between the demand for competencies of logistics skills in these two areas. Further, this study also limited its scope of interviewees to 'academics' only, because they could be interviewed easily during the conference. For future research, it is recommended that a team be organized with members from the three regions in Greater China to collect the responses from industry professionals, to ensure a more detailed and in-depth analysis. This, however, will require more research budget and resources. 


\section{References}

Ballou, Ronald H. and Piercy, James E. 1974. A survey of current status and trends in transportation and logistics education. Transportation Journal. 14(2): 27-36.

Chen, T. and Chiang, Y. M. 2006. The differences in the professional skills between the supply in academics and the demand from the international logistics industry. Maritime Quarterly. 15(4): 23-46.

Chen, T. and Chiang, Y. M. 2007. The study of the differences between the programs designed by technological and normal universities for international logistics industry. Educational Policy Forum. 10(2): 69-96.

Dadzie, Kofie, Q. 1998. Management education for physical distribution and logistics. International Journal of Physical Distribution \& Logistics management. 4: 259.

Grammelgaard, Britta and Paul D. Larson. 2001. Logistics skills and competencies for supply chain management. Journal of Business Logistics. 22(2): 27-49.

Lambert Douglas M. and Stock James R. 1999. Strategic Physical Distribution Management. Richard D. Irwin Inc.

Max, M. 2002. Transportation and Logistics. Fisher College of Business, Ohio State University.

Mohammed Abdur Razzaque and Mas Shafeen Bin Sirat. 2001. Skill requirements: perception of the senior asian logisticians. International Journal of Physical Distribution \& Logistics Management. 31(5): 374-396.

Murphy Paul, R. and Poist Richard, F. 1991. Skill requirements of senior-level logistics executives: an empirical assessment. Journal of Business Logistics. 12: 73-92.

Murphy Paul, R. and Poist Richard, F. 1994. Educational strategies for succeeding in logistics: a comparative analysis. Transportation Journal. 33: 36-49.

Murphy Paul, R. and Poist Richard F., Jr. 1998. Skill requirements of senior-level logistics practitioner perspectives. International Journal of Physical Distribution \& Logistics Management. 28: 284.

Pagliari, Leslie R. 2005. Developing a global logistics course. Journal of Commerce. 6: 14-36.

Report of China Logistics Development 2007. published by China Machine Press, p. 100.

Report of China Logistics Investment and Development 2008. published by Institute of China Uniway Economics. p. 235.

Saaty, Thomas. L. 1980. The Analytic Hierarchy Process. N. Y.: McGraw-Hill Inc.

Stock, James R. and Douglas M. Lambert. 2001. Strategic Logistics Management (4th ed.). Boston: McGraw-Hill Irwin.

Williams, Alan W. and Currey, Peter. 1990. Desired attributes of logistics managers and a learning hierarchy in management education. Logistics Transportation Review. 26: 369-380.

World Bank 2007. Trade Logistics in the Global Economy. 
